\title{
LABORATORY COMPARISON OF nZVI / S-nZVI EFFICIENCY IN SYSTEMS WITH AND WITHOUT POWER
}

\author{
${ }^{1}$ Ondřejka VOLOŠČUKOVÁ, ${ }^{2}$ Petra SKÁCELOVÁ, ${ }^{1}$ Alena PAVELKOVÁ, ${ }^{2} J a n$ SLUNSKÝ, \\ ${ }^{1}$ Jaroslav NOSEK
}

${ }^{1}$ Technical University of Liberec, Institute for Nanomaterials, Advanced Technologies and Innovation (CXI), Liberec, Czech Republic, EU, ondrejka.voloscukova@tul.cz, alena.pavelkova@tul.cz, jaroslav.nosek1@tul.cz

${ }^{2}$ NANO IRON, s.r.o., Židlochovice, Czech Republic, EU, skacelova@nanoiron.cz, slunsky@nanoiron.cz

https://doi.org/10.37904/nanocon.2019.8742

\begin{abstract}
The use of $\mathrm{nZVI}$ is well known method for remediation of groundwater contaminated with chlorinated hydrocarbons. The present paper investigates the ability of traditional nZVI and S-nZVI modified with sulphide ion (HS-) to reduce $\mathrm{CHC}$ in real wastewater sample. In the effort to enhance longevity and efficiency of the treatment, experiments were performed under applied voltage (patent 304152, owner MEGA a.s., TUL). Results showed elevated reactivity of $\mathrm{nZVI}$ in reactors with passing voltage. The decomposition of the $\mathrm{CHC}$ in DC supported reactors occurred several times faster than in reactors without added voltage. However, the analysis of products suggests different pathway of decomposition when S-nZVI is used. The main product of reductive dechlorination was acetylene as opposite to regular $n Z V I$ which produced predominantly ethene and ethane. The $\mathrm{nZVI}$ provided with DC showed the most rapid decline of all contaminants in the time frame of 5 days.
\end{abstract}

Keywords: Zerovalent-iron nanoparticles, chlorinated hydrocarbons, surface modification, direct current

\section{INTRODUCTION}

Groundwater is the largest and the most sensitive freshwater source, which primarily serves is to supply the population with drinking water [1]. Thus, groundwater pollution is an emergent issue, therefore more efficient technologies and innovative materials are being sought. The most common type of groundwater contamination is chlorinated hydrocarbons $(\mathrm{CHC})$ mostly due to careless anthropogenic activity [2]. Nano-sized iron particles ( $\mathrm{nZVI)}$, which are efficient as well as environmentally friendly [3], have already been widely and successfully used for remediation of sites contaminated with $\mathrm{CHC}$ [3]. In the reaction of $\mathrm{nZVI}$ with contaminants, chlorinated hydrocarbons are decomposed (reduced) into gaseous products (ethene, ethane, acetylene) (viz. Figure 1) while the nZVI particles are oxidized to form iron oxides which naturally occur in the Earth's crust, where they do not pose a risk to the environment [3,4].

The aim of presented work is to compare the efficiency of the "traditional" commercially available nZVI and $\mathrm{nZVI}$ with the sulphide modification on particles surface (S-nZVI). The behaviour of these two materials was examined under the voltage passage through the reactor system. (patent 304152, owner MEGA a.s. and TUL) [7]. Despite the fact, that the commercially available $\mathrm{nZVI}$ is effectively used for remediation and its behaviour is well known, $\mathrm{nZVI}$ still represents an economically more demanding option of the reactive material for remediation in comparison to traditional techniques, and thus more available and sustainable methods are being investigated to further increase its efficiency and cheaper application [3].

For the enhancement of $n Z V I$ reactivity various surface modifications being developed. One possible approach is the modification of the particle surface by means of formation of a sulphide shell. S.R.C. Rajajayavel et al. 
discovered that the sulphide modified $\mathrm{nZVI}$ achieves up to the order of magnitude increase in reactivity compared to classical nZVI [6]. Due to the surface modification with the sulphide, the sulfation process takes place on the surface of nanoparticles, where sulphides, disulphides and polysulphides are formed and promote the reduction of chlorinated contaminants. The formation of sulphides also helps to reduce unwanted side reactions of $n Z V I$ with water. The added value of sulphide shell nanoiron lies in a positive effect on activity of sulphide bacteria and thus promotes the biological degradation of chlorinated hydrocarbons [5]

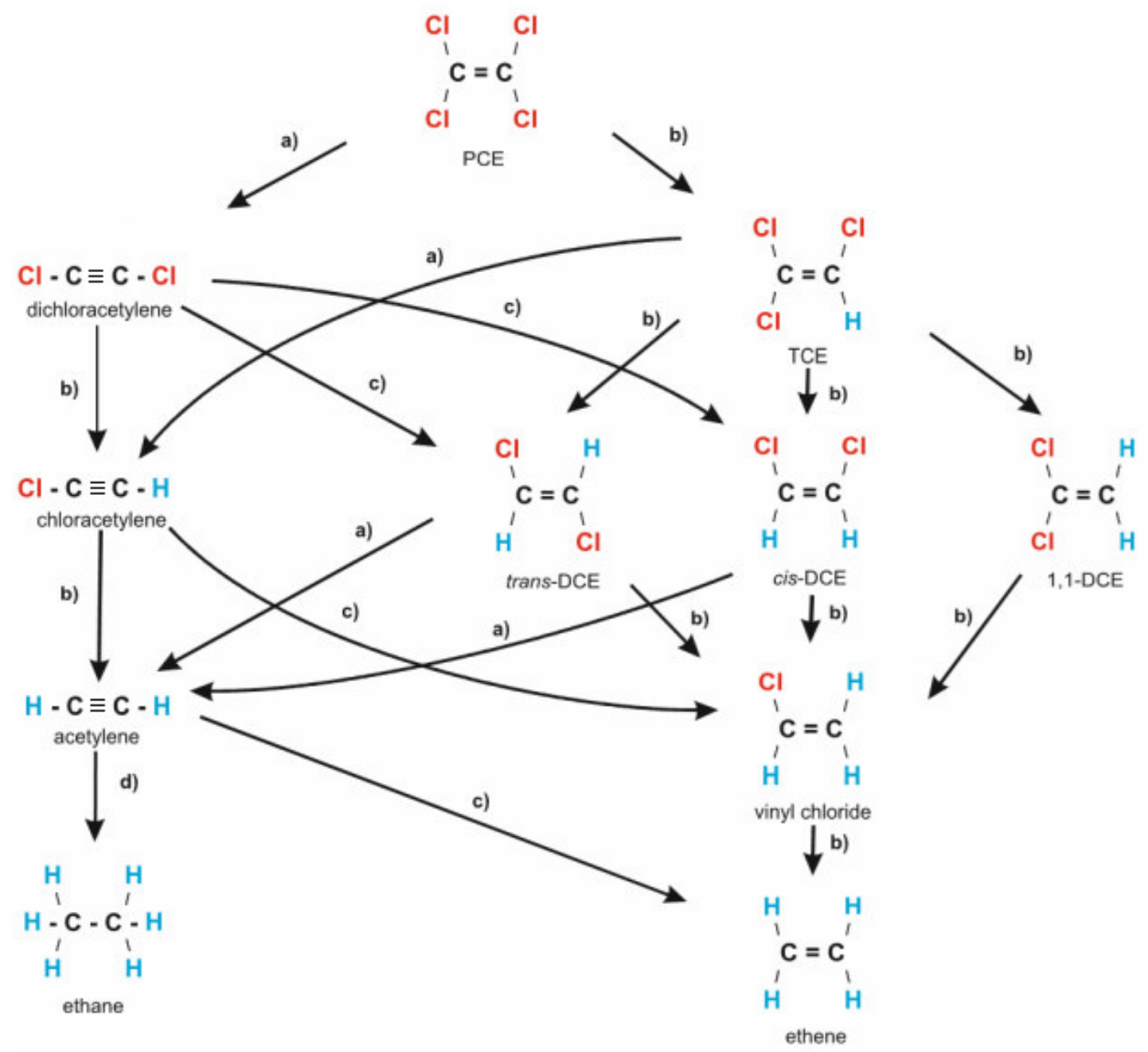

Figure 1 Scheme of decomposition of chlorinated hydrocarbons, where a) reductive dehalogenation, b) hydrogenation, c) reduction of acetylene to ethene, d) reduction of acetylene to ethane.

\section{EXPERIMENTAL SECTION}

\subsection{Materials}

In this research the commercially available nZVI NANOFER STAR and NANOFER 25DS (NANO IRON s.r.o.) were used. Powdered NANOFER STAR consist of $65-85 \%$ of $\mathrm{Fe}^{0}$ and up to $20-35 \%$ of iron oxides, which create a protective shell providing better stability of the $\mathrm{nZVI}$ particles. Second product, NANOFER 25DS is iron with a sulphide coating, around $1 \mathrm{wt} \%$ of sulphides. NANOFER 25DS was received as suspension of $20 \% \mathrm{nZVI}$ in water and used directly without any other treatment or activation. The exact test configuration is shown in Table 1. 
Sample of contaminated groundwater was supplied by Spolchemie a.s., industrial manufacturer of chemicals. The groundwater contaminants were mostly chlorinated ethenes of concentration $10 \mathrm{mg} \cdot \mathrm{L}^{-1}$.

\subsection{Methods}

Experiments were performed in continuously mixed reactors. Glass bottles of $2.5 \mathrm{~L}$ were equipped with stirrer, ports for electrodes and sampling port. Experiment took place in two experimental setups: a) simple reactor, b) reactor with applied direct electric current $(5 \mathrm{~V})$ (viz Figure 2). $2 \mathrm{~L}$ of the contaminated groundwater was poured into reactors and appropriate $\mathrm{nZVI}$ was added to obtain concentration of $2 \mathrm{~g} . \mathrm{L}-1$. The reactors were tightly closed to avoid any leakage; outputs were connected to gas chromatograph for the online data recording.

Table 1 Test configuration

\begin{tabular}{|c|c|c|c|}
\hline label & nZVI used [2 g.L-1] & reactor & DC \\
\hline 1 & $\mathrm{nZVI}$ & a) & - \\
2 & S-nZVI & a) & $5 \mathrm{~V}$ \\
\hline $1+\mathrm{DC}$ & $\mathrm{nZVI}$ & b) & $5 \mathrm{~V}$ \\
\hline
\end{tabular}

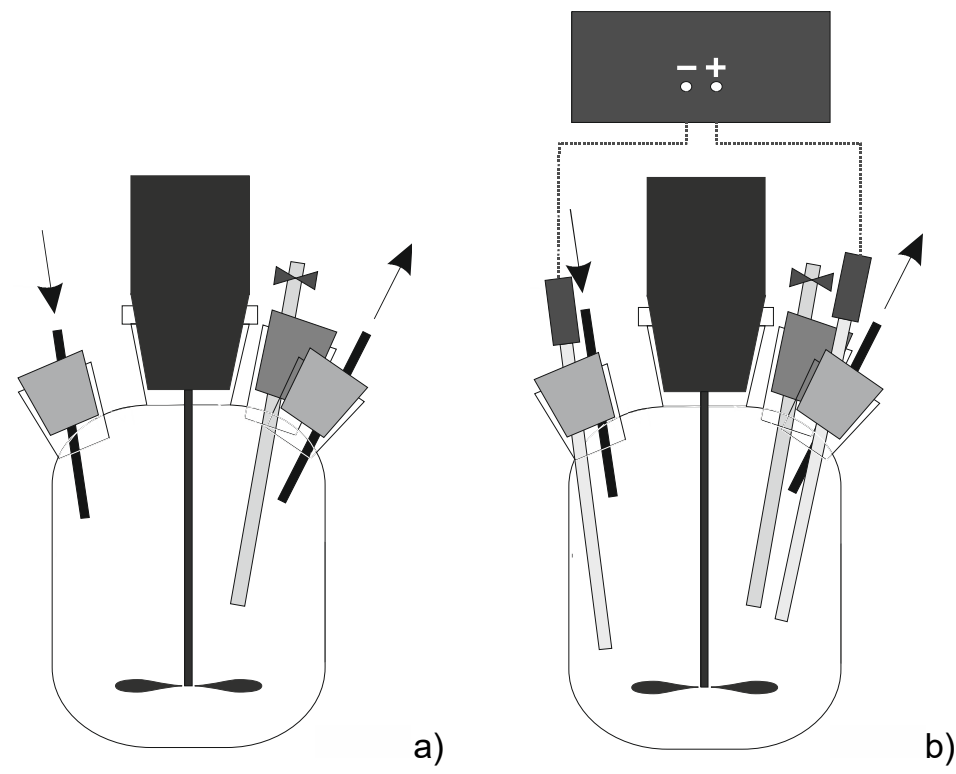

Figure 1 Reactor test configurations: a) a simple reactor; b) reactor with electrodes

During the test, the reactors were sampled for $0,1,3,7,11,14,16,18,21$ and 23 days. At each sampling, physico-chemical parameters were measured and recorded; afterwards the analysis of concentration of the contaminants and dechlorination products was performed.

Physico-chemical parameters ( $\mathrm{pH}$, ORP, conductivity) were measured using a Multi 3430 Multimeter from WTW, Measurement and Analytical Technology, s.r.o.

CHC were measured by GC/MS (Thermo Trace 1310) (Thermo TSQTM 8000 EVO).

The concentration of reductive dehalogenation products (methane, ethane, ethene, acetylene) was measured by GC/FID (Varian Saturn 3800). 
The concentration of ions was determined in the laboratory č. 1243 accredited by ČIA according to ČSN EN ISO/IEC 17025:2005. The standard used for the determination of ions was ČSN EN ISO 10304-1.

\section{RESULTS AND DISCUSSION}

\section{1. $\mathrm{pH}, \mathrm{ORP}$, conductivity development within reductive dechlorination}

At the beginning of the experiment the $\mathrm{pH}$ value of water was slightly over 7 in all reactors. (Figure 3) Within several days the increase of $\mathrm{pH}$ was observed, however the reactor with S-nZVI showed the more moderate progress, likely as the result of sulphide shell protecting $\mathrm{nZVI}$ from fast reductive reaction with water when $\mathrm{OH}^{-}$ groups are generated. Anyway, later the $\mathrm{pH}$ of modified S-nZVI has reached similar values as in reactors provided with $D C$, whereas simple $n Z V I$ exhibited gradual decreasing tendency what could signalize reducing of $n Z V I$ reactivity. The decrease of the ORP has the same trend in all reactors because of reductive capacity of $\mathrm{nZVI}$ and applied DC, which lowering ORP even alone. [8] Nevertheless, in the reactor 1, decreasing reductive ability occurs when the ORP slowly increase. The level of conductivity in the reactor can be attributed to several factors. One of them is presence of dissolved ions, which become less soluble when $\mathrm{pH}$ change; in general, the conductivity increases in low $\mathrm{pH}$, what can be seen in reactor 1 . In other words, the decrease of conductivity is connected to reduction of ions what was also proved by ion determination (Table 2). In the reactors $2,1+\mathrm{DC}$ and $2+\mathrm{DC}$ the amount of $\mathrm{HCO}_{3}{ }^{-}$was significantly reduced and thus the conductivity decreased.
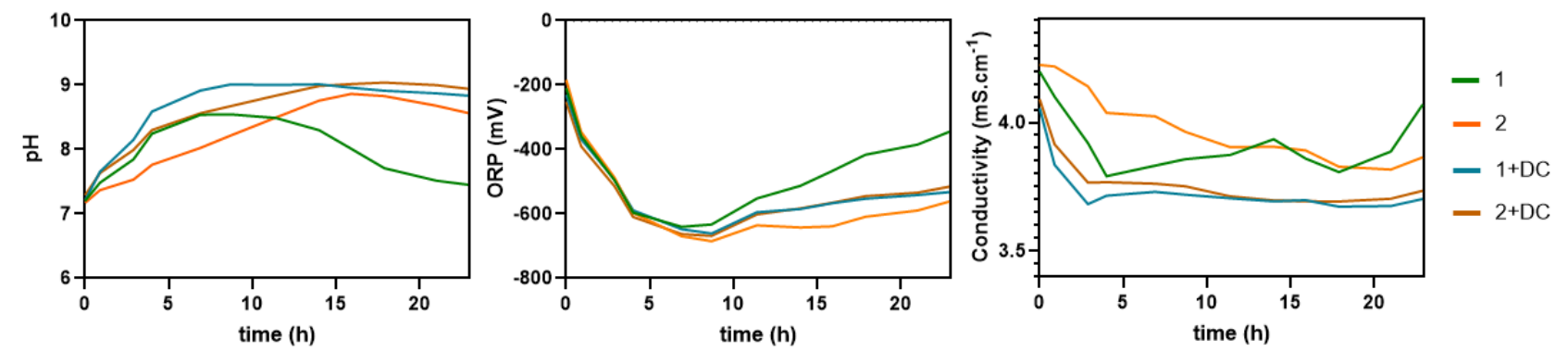

Figure 3 Physico-chemical parameters

Table 2 Chemical composition of groundwater

\begin{tabular}{|c|cccc|}
\cline { 2 - 5 } \multicolumn{1}{c|}{} & $\begin{array}{c}\mathrm{SO}_{4}{ }^{2-} \\
\mathrm{mg} \cdot \mathrm{L}^{-1}\end{array}$ & $\begin{array}{c}\mathrm{HCO}_{3}^{-} \\
\mathrm{mg} \mathrm{L}^{-1}\end{array}$ & $\begin{array}{c}\mathrm{NO}_{3}^{-} \\
\mathrm{mg} \cdot \mathrm{L}^{-1}\end{array}$ & $\begin{array}{c}\mathrm{Cl}^{-} \\
\mathrm{mg} \cdot \mathrm{L}^{-1}\end{array}$ \\
\hline Init & 1290 & 366 & $<5.00$ & 583 \\
1+DC & 1120 & 0 & $<5.00$ & 648 \\
$2+\mathrm{DC}$ & 1140 & 262 & $<5.00$ & 651 \\
1 & 1260 & 12 & $<5.00$ & 641 \\
2 & 1190 & $<5.00$ & 634 \\
\hline
\end{tabular}

\subsection{Products of reductive dechlorination}

The main observation from the experiments is the reactivity of both $n Z V I$ and S-nZVI supported with DC was remarkably higher. The decomposition of $\mathrm{CHC}$ in configuration 1+DC and 2+DC occurred within 10 days unlike the decomposition in reactors 1 and 2 where levels of DCE and VC were present even after 20 days (Figure 4). 
In the graphs of the development of dechlorination products, the reactions $\mathrm{nZVI}$ and S-nZVI with CHC take place via different reaction route (Figure 5). S-nZVI decomposes TCE through formation of vinyl chloride and acetylene what suggest that TCE was reduced via reductive $\beta$-elimination (according to scheme, Figure 1), when triple $\mathrm{C}-\mathrm{C}$ bond is formed. Acetylene is further reduced to ethene and ethane and vinyl chloride is reduced to ethene. What to highlight is the effect of DC when residual DCE and VC, which reduction can be less efficient, were reduced significantly faster than without DC.
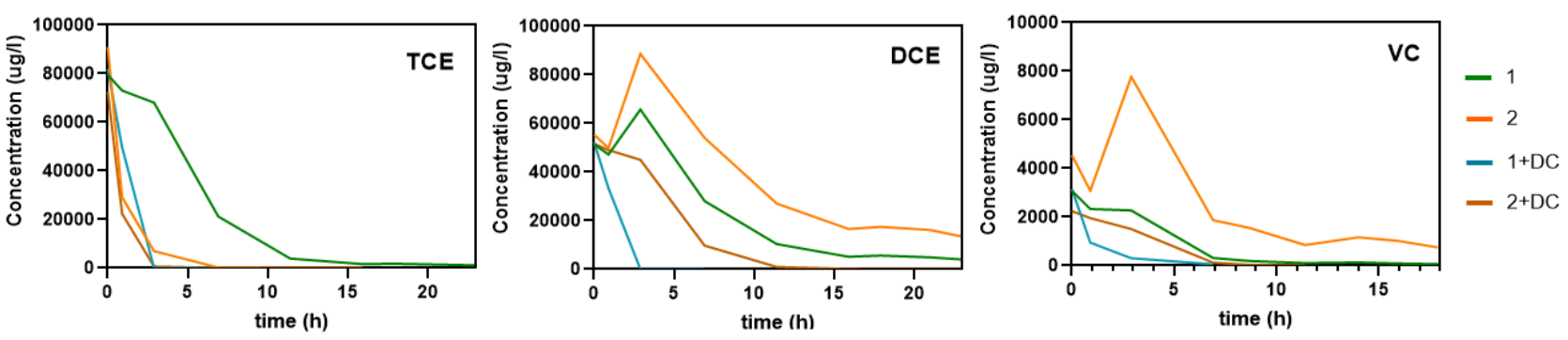

Figure 4 Concentration of $\mathrm{CHC}$
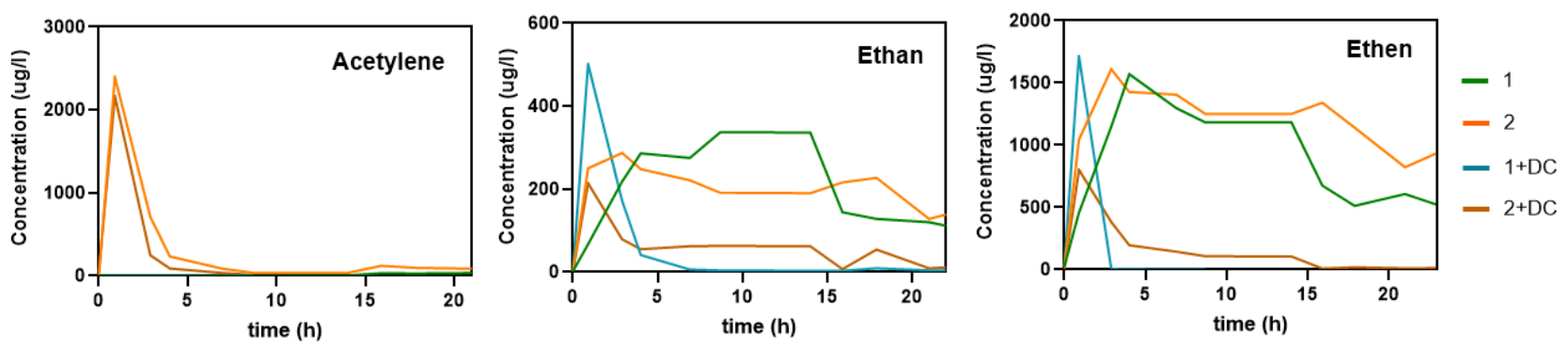

Figure 5 Concentration of dechlorination products

\section{CONCLUSION}

The main object of this research was to investigate reactivity of $n Z V I$ and $n Z V I$ modified with sulphides under an applied voltage (patent 304152, owner of MEGA a.s. and TUL). The results showed similar reactivity of both $n Z V I$ and S-nZVI, however the various reactive pathway was proved. S-nZVI reduced contaminants mostly via trans-DCE, what was discovered based on the analysis of products, which were mainly acetylene and vinyl chloride. After application of direct current into the reactors, dechlorination was significantly accelerated for both $\mathrm{nZVI}$ and S-nZVI. The nZVI system with DC current showed a $100 \%$ decrease in VOC concentrations already after three days, the S-nZVI system with DC current shows the same efficiency after 9 days.

\section{ACKNOWLEDGEMENTS}

The authors gratefully acknowledge the support by the Technology Agency of the Czech Republic "Competence Centres" (project TE01020218).

\section{REFERENCES}

[1] Ministerstvo životního prostředí, Podzemní vody [online], [viewed 2019-10-09]. Available from: https://www.mzp.cz/cz/podzemni vody 
[2] Ministerstvo životního prostředí, Vyhodnocení starých zátěží z hlediska ohrožení hydrosféry nebezpečnými látkami [online], Date: 17. 8. 2016 [update] [viewed 2019-10-09]. Available from:https://heis.vuv.cz/data/webmap/datovesady/projekty/starezateze/default.asp?lang=\&tab=11\&wmap=

[3] FU, F., DIONYSIOU, D.D., LIU, H. The use of zero-valent iron for groundwater remediation and wastewater treatment: a review. J. Hazard. Mater.2014. 267, 194-205.

[4] WEIDLICH, T., LACINA, P. Využití reduktivní dehalogenace pro jednoduchý rozklad aromatických chlorderivátů s následnou biodegradací vznikajících produktů. In Inovativní sanační technologie ve výzkumu a praxi XVIII. 2015. pp. 117-121.

[5] FAN, D., LAN, Y., TRATNYEK, P. G. JOHNSON, R. L., FILIP, J.; O'CARROLL, D. M., GARCIA, A. N., AGRAWAL, A. Sulfidation of iron-based materials: A review of processes and implications for water treatment and remediation. Environ. Sci. Technol. 2017, 51 (22), 13070-13085

[6] RAJAJAYAVEL, S.R.C., GHOSHAL, S. Enhanced reductive dechlorination of trichloroethylene by sulfidated nanoscale zerovalent iron,Water Res. 2015, 78, pp. 144-153

[7] HRABAL, J.; ČERNÍK, M.; NOSEK, J.: The method of in situ remediation of subsurface contaminated by harmful chemical substances. Patent: 304152, accepted 9.10.2013, MEGA a.s., Technical University of Liberec

[8] ČERNÍK, M.; NOSEK, J.; FILIP, J.; HRABAL, J.; ELIOT, D., W.; ZBOŘIL, R.; Electric-Field Enhanced Reactivity and Migration of Iron Nanoparticles with Implications for Groundwater Treatment Technologies: Proof of Concept. Water Research. 2019. 154. pp. 361-69. 